\title{
Practitioners and Library Education: A Crisis of Understanding
}

\author{
Carla J. Stoffle and Kim Leeder
}

\section{Introduction}

The current bellicose dissatisfaction with library education is nothing new; library practitioners have long been vocally critical about both the curriculum and the state of library education as a whole. In a 1985 article in $\mathrm{Li}$ brary Journal, Samuel Rothstein presented "An Anthology of Abuse," documenting in excerpts the criticism LIS programs endured over the course of ninety-four years between 1887 and $1981 .{ }^{1}$ From complaints about the curriculum to attacks on the faculty and students, Rothstein's anthology illustrates the consistency of criticism about LIS education over time. The most telling comment cited by Rothstein is from LIS professor Neil Van Deusen, who observed in 1949 that "practically everything has been said about library schools in the past five years except a kind word." The trajectory of these criticisms continues today in the battle cries of ALA President Michael Gorman and frequent articles_-such as those in this very journal-debating the crisis in library education.

We approach with skepticism both the current implications that library education is in ill health and the recent calls to reform LIS programs by instituting a prescribed curriculum. This skepticism is based partially upon research and partially upon the senior author's experiences-nearly forty years as a practitioner in a variety of positions, a student of higher education, an acting director of a library school, a former ALA Executive Board member, and a current member of the ALA Committee on Accreditation. This blend of experiences has resulted in a very different perspective regarding library education and its needs than that of many of our colleagues. First of all, it is clear to us that ALA holds LIS programs to rigorous standards that are not well understood by the practitioner community. Many practitioners have developed unrealistic expectations for our educational programs in terms of core curriculum, breadth of offerings, and accessibility. Our schools are for the most part too small and modestly funded-with an average of just 13.8 faculty members ${ }^{2}$ and budgets under $\$ 1.5$ million-to be all things to all people, yet we discourage schools from specializing in just a few areas.

The apparent dissatisfaction with LIS programs may be caused by a belief among many practitioners that LIS curricula are not responsive to the 


\section{About the Author}

Carla J. Stoffle is dean, The University of Arizona Libraries and Center for Creative Photography, Tucson (stofflec@u.library.arizona.edu).Kim Leeder is a special assistant to the dean and the director of communications, The University of Arizona Libraries. Ms. received 09/05; accepted 10/05; revised 10/05.

needs of the profession. At the 1977 Conference on Library Orientation for Academic Libraries Charles Bunge, a professor at the University of Wisconsin at Madison, attempted to explain to an audience of bibliographic instruction practitioners why LIS programs could not offer courses in every specialty and how they could cooperate with the programs to resolve concerns about the curriculum. ${ }^{3}$ His comments were not well-received by an audience that felt that LIS programs were disregarding the importance of bibliographic instruction and the felt need for courses in library use instruction. Fifteen years ago when Columbia University's library education program was being disbanded, Richard Dougherty (then ALA President) tried to interest the ALA Executive Board in developing a plan to support Columbia in particular and library education in general. Members of the Board balked, responding with the opinion that library education was out of touch with the needs of the profession and that the faculty deserved to face the consequences. In 1999, the Congress on Professional Education convened to consider the name changes occurring in many LIS programs, the perceived de-emphasis on cataloging and some functional specialties, and practitioners' dissatisfaction with graduates who needed training when beginning new jobs. A result of the first Congress on Professional Education was a practitioner-led effort to define the core values of the profession and the competencies that library school graduates should possess. These values and competencies were then to be incorporated into all library education programs. However, producing such documents has proven much harder to accomplish than anyone expected due to the fact that there is not general agreement on these issues across the profession.

Andrew Dillon and April Norris in "Crying Wolf" have attempted to take the current criticisms of library education, primarily articulated by Michael Gorman, ${ }^{5}$ and debunk them one by one. The most important point in their argument is the attention paid to the curriculum. To support their position that the curriculum is indeed responsive to the profession, Dillon and Norris cite the research of Karen Markey, who analyzed the curricula of fifty-six North American LIS programs and found that there are five core course categories in LIS education. ${ }^{6}$ There is some variation among schools, but on the whole, in Dillon and Norris's words, "there appears to be a general consensus on what a modern LIS curriculum should contain, at least from the perspective of the providers." In addition, Dillon and Norris 
specifically compare Markey's results to Michael Gorman's recommended core curriculum and find that they are, in fact, quite similar. Based on Dillon and Norris's research, we must be convinced not only that there is little evidence supporting the idea that LIS programs are unresponsive to professional needs, but that a more flexible version of the core curriculum Gorman advocates has already been adopted by individual schools of their own accord and in accordance with the ALA Standards for Accreditation of Master's Programs in Library and Information Studies $1992 .{ }^{8}$

\section{Causes of Dissatisfaction}

If one accepts the analysis of Dillon and Norris, why is there a persistent lament in the profession about the inadequacy of library education? And, given the current economic climate, will this continued dissatisfaction lead to an actual decline in the ability of our schools to sustain themselves, especially in research universities? In the end, Dillon and Norris attribute the perception of crisis in library education not to any of the traditional complaints, but to a combination of three elements: the impact of rapid technological change on the profession; an insularity that inhibits relationships between LIS programs and practitioners; and the failure of LIS programs to adequately educate librarians. While we agree with Dillon and Norris that there is no crisis in library education, we must debate their conclusions.

To address the first issue: technology may be sore spot among traditional library practitioners who see its dominance in library school curricula as replacing more important subjects, but it is no more than a peripheral complaint from those who already feel that LIS programs are not good enough. Technology, in and of itself, is not a source of fundamental change in our field; it is only a symptom of other kinds of change. For instance, Markey's research indicates that technology plays only a supporting role in the curriculum of the schools she surveyed: "IT figured prominently into the core curriculum of ILS programs; however, it was not present with the same intensity as core courses in the Organization of Information, Reference, Management, Research, and Foundations of the field." And quite frankly, given our need for people who have the knowledge and abilities to deal with the new technologies in libraries, one might argue that we do not in fact pay enough attention to such understanding and skills, rather than putting too much emphasis on them.

As for the charge of insularity in LIS programs, it is simply not true that faculty and staff do not make connections with those outside of their programs. ALA accreditation requires LIS programs to involve their stakeholders-including students, alumni, and employers (read: practitioners) - in continuous program planning and evaluation, and to show how the program reflects the incorporation of that feedback. In addition, many LIS faculty members play major roles in professional library association activities on the state and national level. Markey points out the relationships LIS programs have with other programs on campus, including dual 
degree programs that have emerged in the last few years, providing expanded course offerings and increasing the interaction of library school faculty with others in the academy. ${ }^{10}$ Furthermore, Charles R. Hildreth and Michael Koenig identify a trend in which seventeen LIS programs were involved in mergers within their academic institutions from 1982 to 2001. "Generally speaking, these LIS schools have been subject to a process that moved them, willingly or not, from a status of relative independence and autonomy (and in many cases, cultural isolation) to that of partners in new alliances, or protected 'adoptees' in new administrative and organizational homes." 11 While the stimulus for these mergers is often financial, the result is an increasing sense of community and "an enhanced intellectual environment." Experience on the COA for the last four years leads us to believe that such mergers have continued since 2001. While many are still uneasy alliances, others have evolved into greater sharing of faculty and capability and an intellectual strengthening of our educational programs, rather than an isolation of faculty from the profession or the institution.

\section{Goals and Standards in Library Education}

So if it is not technology or insularity causing the grievances about library school education, does it really come down to the curriculum? Do LIS programs fail to provide their students with a thorough education in the field? It is our position that the greatest problem with LIS programs is the fact that many practitioners do not understand the goals of library education, the demands under which these programs operate, or the standards to which they are held. Practitioners want to dictate a curriculum based on their interests or the hiring needs of their particular libraries, without acknowledging the tremendous range of subject matter that these schools must address in only 36 to 42 hours of coursework. Feeling in many cases that they had not been fully prepared for their first librarian positions, new practitioners are particularly critical of library education. A 2005 report by the Canadian Library Human Resource Study states that:

Generally, recent entrants into the profession do not believe there is a good match between the course content of their MLIS programs and the demands of the job. While just under two-thirds (63\%) felt their graduate program had provided the general skills and abilities required for library work, less than one-half stated that the problem-solving and information technology skills provided were adequate to effectively perform their jobs ( $45 \%$ and $46 \%$, respectively). ${ }^{12}$

There is a distinction between training and education in library education that is widely acknowledged, but which serves as an apparent source of dissatisfaction among new practitioners who are not aware of the difference. Michael Gorman puts it this way: "Education is the realm of the library schools, but training is the duty of the employing institution." 13 While the needs of the profession should play a role in determining the curriculum, allowing dissatisfied practitioners to dictate the requirements of LIS pro- 
grams will undoubtedly lead to disaster. The goal of today's LIS programs is not to provide specialized training to prepare students for specific positions, but to give students a broad education in the field that will serve as a foundation for any related career path they may choose. In order to provide specialized training, LIS programs would have to be expanded to include more content credit hours and demanding additional credit hours in internships or fieldwork. In the absence of this, LIS programs need to remain generalized and take into account the wide-ranging demands of the profession as a whole in order to best serve their students.

While the ALA Standards for Accreditation of Master's Programs in Library and Information Studies were developed by a committee of the ALA Council and passed in 1992, few practitioners appear to understand the standards or their rigorous application in practice. Essentially, the process includes the following: LIS programs are formally reviewed by ALA's Committee on Accreditation (COA) at least every seven years, but in reality are subject to a rigorous, continuous review process more demanding than the reviews that our universities and colleges undergo. Each program is required to annually submit data on enrollment, staffing, expenditures, etc., and every other year, to submit narratives describing any changes that relate to the requirements of the standards. These reports are carefully examined by the COA, which may call for special reports if members of the committee have questions. Each library program is reviewed under ALA standards and within the context of the mission and goals of the program. The program's mission and goals cannot be dictated by ALA, and must be consistent with institutional mandates.

ALA standards are not easy to satisfy. They require, among other things: a continuous planning program involving relevant stakeholders with evidence that their input has been incorporated; measured student learning outcomes and a curriculum mapped to the outcomes and to the broad areas defined in the standards; evidence to demonstrate that students are constructing coherent programs of study, and that students are admitted with appropriate qualifications for success in the program and the profession; sufficient numbers of faculty who are qualified for the courses they are teaching and able to offer the majority of the required courses; faculty who perform scholarship whether or not it is required by the institution (the amount of scholarship varies with the mission and setting of the school); and sufficient resources and space to meet the mission and numbers of students. Administrative support and leadership from within and outside the program are also addressed in ALA's Standards and reviewed by the COA. Programs are subject to meeting all the standards in substantial ways or face being placed on conditional accreditation. The COA reviews each school's portfolio in detail, and often requires follow-up data. There are very few programs that are able to get through the annual reviews and seven-year accreditation process without being faced with probing questions and requests for additional information.

Considering the situation, we believe that LIS programs as a whole are 
doing a tremendous job of providing an education that is general enough to serve as a strong foundation for all library careers, while offering enough specialized electives to provide some focus in particular directions. All schools describe their admission standards in accreditation program reports, which are generally available for public review. The standards for admission are typically high, as students must meet at a minimum the criteria for admission to graduate study at their institutions, and some programs require substantially higher criteria than their institutions. Accreditation teams do check to see that schools are meeting the standards they set and there are generally no reports that such criteria are not being met. Finally, our own experience with students and new librarians all across the country leads us to have great faith in the schools and their graduates. This is not to say that our programs could not be better, or to absolve them from a consistent effort to be at the forefront of the profession, but they are certainly successful in meeting the multifarious demands placed upon them and graduating librarians who are knowledgeable and capable, if not trained for specific positions.

Despite assertions to the contrary, the ALA accreditation process holds our LIS programs to a very high quality level for program delivery and research, and most programs meet or exceed the standards. Very few schools are put on conditional accreditation, and no accreditation has been withdrawn since the 1999 events at the University of Arizona School of Information Resources and Library Science, which resulted in changes in the process - not the standards - as well as improvements in communication between LIS programs and the COA. Given ALA's standards as enforced by the COA, it is difficult to see any support for the practitioner obsession with the decline of library education. The calls for massive reform and required standardization of curricula, in light of the different missions and different settings for our programs, are naïve to say the least and may actually threaten the viability of our programs, especially in research institutions.

\section{Conclusion}

The crisis in library education is a crisis of understanding. Distanced from LIS programs by their roles in the field, many practitioners have assumed an adversarial role against library education and have been unsympathetic when institutional demands coupled with insufficient funding result in library school programs different from those they envision. Instead of assuming the worst, practitioners should thoughtfully consider how schools are evaluated and what it takes to educate a librarian while seeking cooperative means through which they can help LIS programs more effectively accomplish their goals. As the African proverb goes, it takes a village to raise a child; the education of new librarians is the responsibility of the field as a whole, not just of teaching faculty. LIS programs are small and vulnerable, 
and instead of criticism they need support and involvement from practitioners.

Charles Bunge offers a list of methods through which practitioners can become involved in supporting and improving library education, including serving on LIS program advisory boards, getting involved as a member of an alumni organization, and participating in local or national library education committees. Practitioners can also teach courses, provide mentoring, hire student assistants or interns, and offer aspiring librarians the hands-on experience that coursework is unable to provide. A small number of practitioners already play a critical role in the continuation of LIS programs, through participation in the COA and as members on visiting panels. "Library schools don't function in a vacuum.... LIS education needs a healthy infrastructure involving faculty, students, alumni, and practitioners," observes Ling Hwey Jeng. ${ }^{14}$ The trouble is that if practitioners continue the loud and destructive criticism, and if they do not step up to the plate to offer real resources and financial support, they will create a self-fulfilling prophesy: LIS programs that cannot succeed, and a real decline in library education. Taking a more constructive (though not prescriptive) approach to dealing with concerns about library education will better serve everyone involved, including the schools, students, and practitioners.

\section{References}

1. Samuel Rothstein, "Why People Really Hate Library Schools," Library Journal 110 (April 1985): 42-43.

2. Timothy W. Sineath, "Faculty," in Library and Information Science Education 2003 Statistical Report, ed. Association for Library and Information Science Education, http://ils.unc.edu/ALISE/2003/Faculty/Faculty01.htm (Oak Ridge, TN: Association for Library and Information Science Education, 2003).

3. Charles A. Bunge, "Library Education for Library Instruction: How the Practitioners and the Educators Can Cooperate," Putting Library Instruction in its Place: In the Library and in the Library School, ed. Carolyn A. Kirkendall, 65-70 (Ann Arbor: Pierian Press, 1978).

4. This issue.

5. Michael Gorman, "Whither Library Education?" New Library World 105 (2004): 376-380.

6. Karen Markey, "Current Educational Trends in the Information and Library Science Curriculum," Journal of Education for Library and Information Science 45 (Fall 2004): 317-339.

7. This issue, [add page number from proofs].

8. American Library Association, "Standards for Accreditation of Master's Programs in Library and Information Studies 1992," American Library Association, http://www. ala.org/ala/accreditation/accredstandards/standards.htm (accessed October 27, 2005).

9. Markey, 319.

10. Markey, "Current Educational Trends," 322.

11. Charles R. Hildreth and Michael Koenig, "Organizational Realignment of LIS Programs in Academia: From Independent Standalone Units to Incorporated Programs," Journal of Education for Library and Information Science 43 (2002): 128, 131. 
12. Ernie Ingles, Kathleen De Long, Chuck Humphrey, Allison Sivak, Marianne Sorensen, and Jennifer de Peuter, The Future of Human Resources in Canadian Libraries (Edmonton, Alberta, Canada: Canadian Library Human Resource Study, 2005), http://www.ls. ualberta.ca/8rs/8RsFutureofHRLibraries.pdf, 122.

13. Gorman, "Whither Library Education?" 377.

14. Ling Hwey Jeng, "The Points of ALA Task Force on Library School Closing," PRISM 13 (Fall 2005), http://www.ala.org/ala/accreditation/prp/prism/current/ demystifyingcoawhatsbehindthestandards/TFLSC.htm. 